\title{
Przegląd działań wybranych, sieciowych produktów turystycznych subregionu siedleckiego
}

\author{
Barbara Dymna
}

\section{STRESZCZENIE}

W latach 2011-2013 Mazowiecka Regionalna Organizacja Turystyczna (MROT) wraz z interesariuszami rynku turystycznego, realizując projekt Podnoszenie konkurencyjności turystycznej Mazowsza poprzez wdrażanie sieciowych produktów turystycznych, opracowała i skomercjalizowała 16 takich ofert turystycznych.

Zaproponowane sieciowe produkty turystycznych są próbą przezwyciężenia problemu, jakim jest brak integracji pomiędzy ofertą turystyczną Warszawy a walorami dotychczas niewykorzystanymi w subregionach: siedleckim, radomskim, płockim, ciechanowskim i ostrołęckim. Rozwój turystyki poprzez komercjalizację tych usług jest jedną z możliwości ożywienia społeczno-gospodarczego ww. subregionów. Funkcjonowanie produktów turystycznych wymaga ciągłego zaangażowanie liderów i partnerów oraz wsparcia merytorycznego i finansowego ze strony administracji samorządowej województwa i organizacji turystycznych, w tym Mazowieckiej Regionalnej Organizacji Turystycznej.

Celem artykułu jest charakterystyka trzech, spośród ww. 16, sieciowych ofert turystycznych: Wielki Gościniec Litewski, Mazowiecka Micha Szlachecka i Kraina Mistrza Twardowskiego funkcjonujących w subregionie siedleckim. W artykule przedstawiono działania promocyjne i organizacyjne podejmowane na rzecz rozwoju takich usług sieciowych i ich umocnienia na rynku turystycznym, na przestrzeni ostatnich 5 lat. Intensywność działań osób zaangażowanych $\mathrm{w}$ tworzenie ww. ofert stanowiła podstawę do zakwalifikowania ich przez MROT do grupy produktów najbardziej zaawansowanych w komercjalizacji.

Słowa kluczowe: sieciowy produkt turystyczny, działania promocyjne i organizacyjne, rozwój społeczno-gospodarczy

\section{Wstęp}

Mazowsze jest postrzegane jako region niezbyt atrakcyjny turystycznie. Wybór województwa mazowieckiego jako destynacji turystycznej najczęściej ogranicza się do Warszawy, która jest liczącym się centrum ruchu turystycznego. Wynika to ze stołecznego charakteru miasta oraz zlokalizowania w nim licznych atrakcji turystycznych. Walory turystyczne pozostałej części województwa mazowieckiego są mało znane i region, z wyjątkiem Warszawy, jest niewystarczająco rozpoznawalny na mapie turystycznej Polski. Sieciowe produkty turystyczne, przy konsekwentnej promocji i ciągłym rozwijaniu ich oferty mogą stać się szansą na zmianę tego stanu rzeczy, bowiem oprócz atrakcji turystycznych zlokalizowanych w Warszawie, Płocku, Żelazowej Woli i Opinogórze, w całym regionie istnieje wiele niemniej interesujących obiektów zabytkowych, miejsc historycznych oraz atrakcji przyrodniczych, na bazie których zostały one wyłonione.

W celu podniesienia konkurencyjności województwa i wykreowania wizerunku Mazowsza, jako regionu atrakcyjnego turystycznie, w latach 2011-2013 Mazowiecka Regionalna Organizacja Turystyczna wraz z interesariuszami rynku turystycznego 
opracowała 16 sieciowych produktów turystycznych usystematyzowanych w 4 markach parasolowych: Historia, Smaki i Tradycje, Kultura i Sztuka oraz Aktywnie. Trzy produkty funkcjonują w obszarze subregionu siedleckiego:

- Wielki Gościniec Litewski pod marką parasolową Historia,

- Szlak folkloru i smaków Mazowsza pod marką parasolową Smaki i Tradycje,

- Legendy i Baśnie Mazowsza pod tą samą marką.

Celem artykułu jest charakterystyka ww. sieciowych produktów turystycznych, których obszarem realizacji są powiaty: siedlecki, sokołowski, węgrowski oraz miasto Siedlce w subregionie siedleckim. Wielki Gościniec Literwski jest ponadto realizowany w powiecie mińskim i m.st. Warszawa. W artykule przedstawiono działania podejmowane na rzecz rozwoju sieciowych produktów i ich umocnienia na rynku turystycznym. W grupie wymienionych wyżej 16 ofert był produkt pt. Śladami nadbużańskich tajemnic, którego obszarem rozwoju był również subregion siedlecki. Produkt jednak w bardzo krótkim czasie po komercjalizacji zaprzestał swojej działalności, dlatego nie został opisany.

Według Polskiej Organizacji Turystycznej sieciowy produkt turystyczny to gotowa do sprzedaży, „spakietyzowana” oferta opierająca się o rozproszoną strukturę podmiotów, atrakcji, miejsc, punktów obsługi i obiektów, funkcjonujących jako jedna spójna koncepcja, posiadająca wspólny, wiodący wyróżnik (markę). Tworzenie sieciowego produktu turystycznego jest ciągłym procesem. Produkt funkcjonuje, jeżeli działa system wdrażających go partnerów, jeżeli ponoszone są nakłady na jego rozwój, a przede wszystkim, jeżeli są turyści korzystający z oferty i generujący dochody dla partnerów. Wybór 16 sieciowych produktów turystycznych był efektem realizacji przez Mazowiecką Regionalną Organizację Turystyczną projektu „Podnoszenie konkurencyjności turystycznej Mazowsza poprzez wdrażanie sieciowych produktów turystycznych". Do realizacji wybrano najbardziej zaawansowane produkty, za których komercjalizację odpowiedzialni byli liderzy. Pierwszym zadaniem liderów było zbudowanie sieci podmiotów współpracujących ze sobą oraz opracowanie atrakcyjnych projektów dla turystów. Następnie przygotowano pakiety ofert turystycznych gotowych do sprzedaży przez biura podróży lub punkty informacji turystycznej. Oferty na sezon letni i zimowy zawarto w Katalogu Produktowym Mazowsze Lato-Zima 2013-2014. W celu promocji produktów uruchomiona została strona internetowa, opracowano logo oraz materiały graficzne: broszury i ulotki. Prace podejmowane w dalszej kolejności polegały na udoskonalaniu wykreowanych produktów turystycznych. Działania liderów i partnerów wspomagała Mazowiecka Regionalna Organizacja Turystyczna poprzez organizację szkoleń, warsztatów i konferencji. W latach 2016-2017 przygotowano katalog Produkty turystyczne województwa mazowieckiego, a każdemu z nich poświęcony jest osobny rozdział, w którym wyeksponowano główną atrakcję i opisano pozostałe punkty szlaku. Opracowano również 80 uaktualnionych kart reklamowych bardziej przystosowanych do wymagań rynku, zawierających oferty partnerów współpracujących w ramach poszczególnych produktów. Karty ofertowe zawierają skrócone informacje o atrakcjach, adres partnera i cenę oferty. Dla zwiększenia dostępności ofert opracowano specjalne ekspozytory kart ofertowych, które umieszczono w 35 centrach i punktach informacji turystycznej 
w Warszawie oraz w ważniejszych węzłach turystycznych regionu. Zainicjowano wzajemną promocję partnerów oraz rozpowszechnianie ich ofert $\mathrm{w}$ regionalnej i lokalnej prasie, mediach społecznościowych oraz mazowieckich, turystycznych serwisach internetowych: www.mazowsze.travel, www.modanamazowsze.pl oraz www.mrot.pl. Uproszczono nazwy niektórych produktów np. Szlak folkloru i smaków Mazowsza funkcjonuje obecnie pod nazwą Folklor i Smaki Mazowsza. Wszystkie podejmowane działania miały na celu przede wszystkim promocję sieciowych produktów turystycznych, ugruntowanie ich pozycji na rynku oraz rozszerzenie sieci współpracy [Majewska i in. 2008; Program rozwoju... 2011; Kachniewska 2015; Gadomska (red.) 2015; Dymna 2018].

\section{Charakterystyka i opis działań podejmowanych w ramach funkcjonowania sieciowych produktów turystycznych w subregionie siedleckim}

\section{Wielki Gościniec Litewski}

Wielki Gościniec Litewski to historyczny szlak drogowy, który w okresie Rzeczypospolitej Obojga Narodów łączył Warszawę i Wilno. Szlak ten był przez kilka wieków jednym z najważniejszych traktów handlowych i pocztowych. Rozpoczynał się w Warszawie, następnie biegł przez Sulejówek, Stanisławów, Dobre, Liw, Węgrów, Sokołów Podlaski, Drohiczyn, Bielsk Podlaski, Białystok i Grodno do Wilna. Zawarcie unii polsko-litewskiej w XV w. spowodowało unormowanie stosunków między oboma państwami oraz ożywienie handlowe i gospodarcze wzdłuż szlaku. Istnienie szlaku miało wpływ na sprawne funkcjonowanie komunikacji w granicach dużego państwa, ale również na rozwój miejscowości przy nim usytuowanych. Czasy największej świetności szlaku przypadają na XVIII w., co wiązało się z upowszechnieniem dyliżansu podnoszącego komfort podróży. W czasach saskich gościniec stał się również jednym z najważniejszych traktów pocztowych. Stracił on na znaczeniu po wprowadzeniu komunikacji kolejowej w XIX w., a do jego schyłku przyczyniły się również rozbiory Rzeczypospolitej.

Po dwóch wiekach od utraty znaczenia traktu pojawił się pomysł jego reaktywacji jako szlaku turystycznego biegnącego z Warszawy do Wilna (ryc. 1). Duży potencjał turystyczny miejscowości położonych wzdłuż historycznego szlaku stanowił podstawę zbudowania sieciowego produktu turystycznego pod nazwą Wielki Gościniec Litewski. W celu realizacji przedsięwzięcia, w 2012 r., powołano Lokalną Organizację Turystyczną Wielki Gościniec Litewski (LOT WGL), która została liderem produktu. Stowarzyszenie zrzesza 48 podmiotów, w tym samorządy, instytucje kultury, organizacje pozarządowe oraz właścicieli obiektów turystycznych.

Oferta tego produktu obejmuje atrakcje proponowane przez Muzeum J. Piłsudskiego w Dworku „Milusin” (Sulejówek), Muzeum Konstantego Laszczki (Dobre), Muzeum Zbrojownia na Zamku w Liwie. Obejmuje również zabytki Węgrowa, w tym Bazylikę Mniejszą z magicznym lustrem Mistrza Twardowskiego, zabytkowy zespół cukrowni „Elżbietów” w Sokołowie Podlaskim oraz zabytki Drohiczyna (województwo podlaskie). 
Podróż historycznym szlakiem daje także możliwość korzystania z oferty partnerów produktu np. obiektu "Gościniec Goździejewski” (Kąty Goździejewskie, gmina Dębe Wielkie), gospodarstwa agroturystycznego „Mitowska Zagroda” (Seroczyn, gmina Sterdyń) lub Zagrody Edukacyjnej „Latosowo” (Henrysin, gmina Kosów Lacki). Odwiedzenie tych obiektów to dla turystów szansa poznania oryginalnej, tradycyjnej kuchni oraz możliwość uczestnictwa w różnego rodzaju warsztatach kulinarnych lub rękodzielniczych.

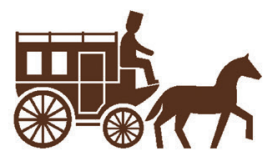

Warszawa Sulejówek

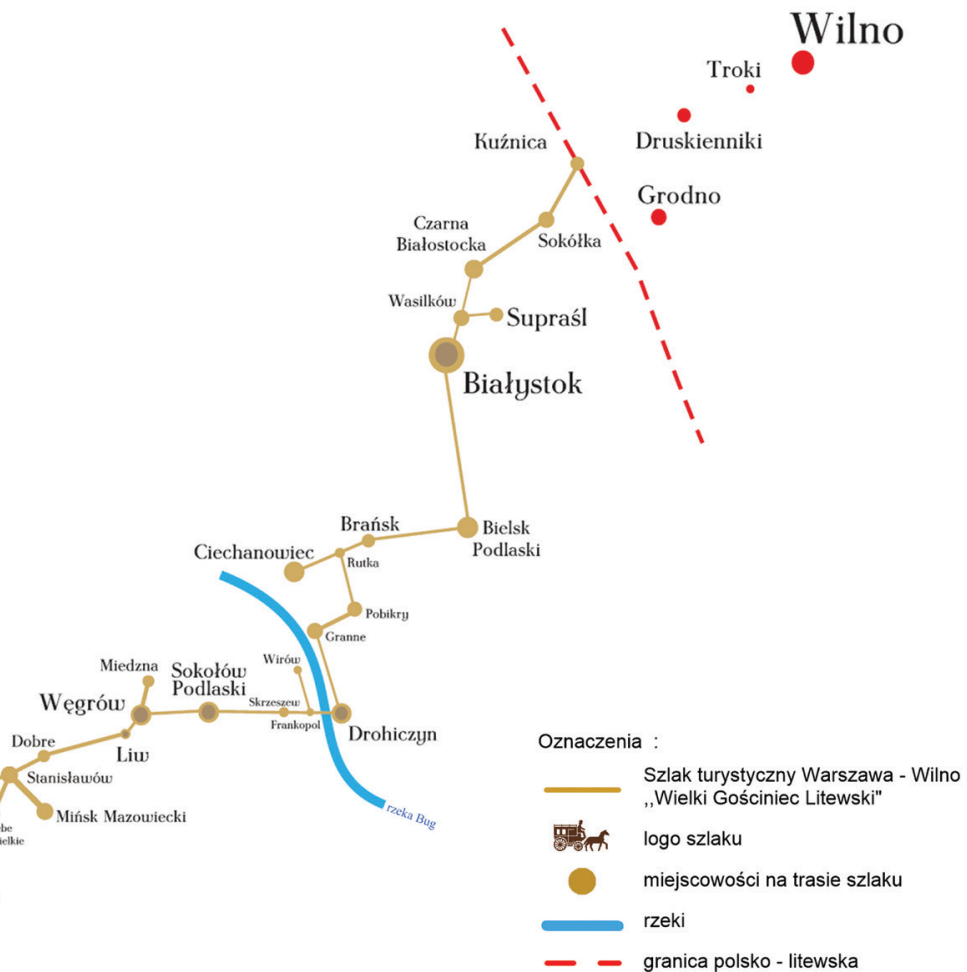

Ryc. 1. Wielki Gościniec Litewski - Szlak Turystyczny Warszawa - Wilno Źródło: Lokalna Organizacja Turystyczna Wielki Gościniec Litewski

W celu udoskonalenia i zwiększenia atrakcyjności produktu turystycznego Wielki Gościniec Litewski lider projektu - LOT WGL podejmuje szereg przedsięwzięć promocyjnych i organizacyjnych.

„Nawet najlepszy w założeniach i funkcjonujący produkt turystyczny nie ma szans na byt rynkowy, jeżeli zabraknie o nim informacji skierowanej do potencjalnych odbiorców. Komunikacja marketingowa, jako proces przekazywania informacji innym podmiotom odgrywa kluczową rolę w kształtowaniu sprzedaży produktu. Nie wiedząc o produkcie konsumenci nie wybiorą go. Stosuje się tutaj powszechnie używane sformułowanie: information is power" [Wilk-Grzywna 2015]. 
Działania promocyjne polegają przede wszystkim na organizacji własnych imprez plenerowych oraz udziale $\mathrm{w}$ imprezach i wydarzeniach targowo-wystawienniczych organizowanych przez inne instytucje, w tym $\mathrm{w}$ targach turystycznych krajowych i zagranicznych. Imprezą plenerową współorganizowaną przez LOT WGL, jest Międzynarodowy Turniej Smaków odbywający się cyklicznie na zamku w Liwie. Jest to największa impreza kulinarna na szlaku Wielkiego Gościńca Litewskiego i jedna z największych imprez tego typu na Mazowszu. Międzynarodowy Turniej Smaków znacząco przyczynia się do promocji produktu turystycznego Wielki Gościniec Litewski, przyciągając lokalnych i zagranicznych wystawców oraz liczne rzesze turystów. W 2018 r. na Turnieju swoje wyroby prezentowało około stu wystawców. Około osiemdziesięciu z nich prezentowało na stoiskach regionalne towary spożywcze, pozostali - rękodzielnicze. Ideą imprezy jest promocja regionalnej żywności, ze szczególnym uwzględnieniem potraw pochodzących z obszaru położonego wzdłuż Wielkiego Gościńca Litewskiego. Promowane są tradycyjne potrawy mazowieckie, podlaskie oraz przysmaki kuchni tatarskiej, litewskiej i białoruskiej. W czasie Turnieju odbywają się konkursy na najsmaczniejszą potrawę ze Szlaku Wielki Gościniec Litewski oraz na Gościniec z podróży, czyli kulinarny podarek ze szlaku. W 2016 r. Polska Organizacja Turystyczna przyznała III Międzynarodowemu Turniejowi Smaków certyfikat Najlepszy Produkt Turystyczny Województwa Mazowieckiego, co świadczy o dużej renomie imprezy.

Oprócz organizacji imprez własnych, lider promuje produkt oraz oferty poszczególnych obiektów podczas imprez organizowanych przez inne instytucje. Promocja odbywa się na własnym stoisku zorganizowanym przez LOT WGL lub poprzez umieszczenie materiałów promocyjnych (ulotek, broszur, map) na stoiskach Mazowsza lub MROT. Działania promocyjne prowadzone są również przez członków stowarzyszenia LOT WGL, przede wszystkim przez właścicieli gospodarstw agroturystycznych, restauracji i atrakcji turystycznych na szlaku. Członkom stowarzyszenia najbardziej zależy na pozyskaniu turystów, bo to oni bezpośrednio odczuwają efekty tej promocji w postaci zwiększonej sprzedaży swoich usług noclegowych i gastronomicznych.

Wielki Gościniec Litewski jest promowany m.in. podczas corocznych turniejów rycerskich „O pierścień księżnej Anny" odbywających się na zamku w Liwie, Dniach Węgrowa organizowanych cyklicznie przez władze miasta, Międzynarodowych Dniach z Doradztwem Rolniczym w Siedlcach. Prestiżowe znaczenie dla promocji produktu Wielki Gościniec Litewski miał udział lidera i partnerów w II Warszawskim Festiwalu Kulinarnym „Królewski Stół” w 2018 r., który odbywał się na terenie Muzeum Pałacu Króla Jana III w Wilanowie. Partnerzy prezentowali tam najlepsze potrawy z regionów, przez które przebiega szlak. Inną prestiżową imprezą podczas której promowano Wielki Gościniec Litewski był Festiwal „Niepodległa”, który miał miejsce 11 listopada 2018 r. na Karkowskim Przedmieściu w Warszawie. W strefie gastronomicznej festiwalu partnerzy produktu prezentowali oryginalną kuchnię ze szlaku. Można było skosztować potraw kuchni mazowieckiej i podlaskiej oraz zakupić „Gościniec z podróży Wielkim Gościńcem Litewskim”, na który składały się przysmaki dwóch wielkich Polaków: kawa „żołędziówka”, którą pijał Fryderyk Chopin oraz „cynamonowe suchary” Marszałka Piłsudskiego. 
LOT WGL, w celu promocji Wielkiego Gościnca Litewskiego, bierze udział w targach turystycznych, w tym również tych najbardziej prestiżowych jak: Międzynarodowe Targi Turystyczne TT Warsaw, Tour Salon w Poznaniu, Międzynarodowe Targi Turystyki Wiejskiej i Aktywnej AGROTRAVEL \& ACTIVE LIFE w Kielcach, Targi „Na Styku Kultur” w Łodzi oraz w targach w Druskienikach na Litwie i w Grodnie na Białorusi. Promocja produktu odbywa się na stoisku przygotowanym przez województwo mazowieckie. Często takim wydarzeniom towarzyszy degustacja „Gościńców z podróży”. Przedstawiciele organizacji LOT WGL, zarówno w celu promocji, jak i zdobywania wiedzy związanej z funkcjonowaniem produktu turystycznego biorą także udział w konferencjach naukowych, w tym również międzynarodowych. Innym rodzajem działań promocyjnych jest udział lub organizacja kiermaszów wielkanocnych i bożonarodzeniowych. Podczas tego typu imprez odbywają się warsztaty tworzenia ozdób świątecznych (np. wycinanki z opłatka) oraz istnieje możliwość prezentacji wyrobów rękodzielniczych i potraw świątecznych. Wielki Gościniec Litewski jest promowany także przy okazji rajdów samochodowych i rowerowych odbywających się na trasie Sulejówek - Wilno. Lider i partnerzy produktu, oferując uczestnikom rajdów swoje usługi, upowszechniają wiedzę o szlaku i jego promocję.

LOT WGL wspiera działania promocyjne producentów wytwarzających artykuły konsumpcyjne, charakterystyczne dla poszczególnych miejscowości na szlaku. Wytwarzane towary są związane historycznie z daną miejscowością lub poprzez swoją nazwę nawiązują do miejsca, w którym powstają. Turyści mogą je nabywać w poszczególnych miejscowościach położonych na szlaku. Podejmowane działania przyczyniły się do powstania: kawy „żołędziówka" sprzedawanej w Kątach Goździejewskich (gmina Dębe Wielkie), „cynamonowych sucharów Marszałka” w Sulejówku, ciastek „księżyce Twardowskiego” w Węgrowie, ciastek „sokółki” w Sokołowie Podlaskim oraz wielu innych artykułów dostępnych w gospodarstwach agroturystycznych.

Do promocji i rozwoju produktu turystycznego przyczynia się też współpraca LOT WGL z wieloma instytucjami i organizacjami m.in. z: Urzędem Marszałkowskim Województwa Mazowieckiego w Warszawie, Polską Organizacją Turystyczną Mazowiecką Organizacją Turystyczną i Podlaską Regionalną Organizacją Turystyczną z uczelniami wyższymi m.in. z Uniwersytetem Przyrodniczo-Humanistycznym w Siedlcach i Wyższą Szkołą Wychowania Fizycznego i Turystyki w Białymstoku. LOT WGL współpracuje z biurami podróży i przewodnikami turystycznymi, muzeami i obiektami turystycznymi na szlaku, a także z mediami zagranicznymi, krajowymi i regionalnymi.

Oprócz działań promocyjnych podejmowane są również działania organizacyjne i inwestycyjne. W 2015 r. w ramach działalności LOT WGL otwarto Szlak Unitów Sokołowskich. Jest to jedyny w Polsce szlak poświęcony unitom podlaskim prowadzący przez dawne cerkwie unickie, obecnie kościoły w powiecie sokołowskim.

Organizacyjny wymiar miało utworzenie w 2017 r. Akademii kulinarno-historycznej im. Wojciecha Wielądko. Akademia jest organem doradczym funkcjonującym w strukturach LOT WGL. Jej działania mają na celu nadzór merytoryczny nad turniejami smaków oraz podniesienie świadomości znaczenia tradycji kulinarnych regionu. 
Bardzo ważnym działaniem organizacyjnym było oznakowanie w 2018 r. Szlaku Wielki Gościniec Litewski. Ustawione znaki wskazują jego przebieg oraz informują turystów o dostępnych atrakcjach.

Na zwiększenie atrakcyjności produktu turystycznego Wielki Gościniec Litewski wpływ będzie mieć przebudowa i modernizacja zamku w Liwie. W ramach inwestycji przeprowadzono wiele prac rekonstrukcyjnych i renowacyjnych $\mathrm{w}$ zamku oraz $\mathrm{w}$ jego najbliższym otoczeniu. Wybudowano przystań kajakową na rzece Liwiec, przenośne wiaty drewniane, plac zabaw dla dzieci w stylizacji średniowiecznej oraz przygotowano pole namiotowe. Realizacja inwestycji umożliwiła utworzenie parku kulturowo-historycznego przy zamku oraz przyczyni się do poszerzenia oferty edukacyjnej i turystycznej tego obiektu.

Warto podkreślić, że lider i partnerzy realizujący produkt Wielki Gościniec Litewski intensywnie współpracują ze sobą. Wspólny cel jego promocji, jako ciekawego kierunku turystycznego, poprzez kulinaria i ofertę edukacyjna, daje wiele możliwości rozwoju każdemu podmiotowi zaangażowanemu w ten projekt. Partnerzy zauważają zarówno potrzebę wspólnej promocji, wymiany doświadczeń i uzupełniania oferty o brakujące elementy, jak również efekty tej współpracy, która owocuje coraz większym zainteresowaniem turystów ofertą produktu i wzrostem jego popularności.

O skuteczności podejmowanych działań promocyjnych i organizacyjnych świadczą również wyróżnienia otrzymane przez produkt. W 2017 r. Szlak Wielki Gościniec Litewski został wyróżniony w konkursie EDEN (European Destination of Excellence) na etapie krajowym. Wyróżnione miejsca charakteryzują się ciekawą ofertę turystyczną oraz dbałością o środowisko przyrodnicze i lokalne dziedzictwo kulturowe. Wyróżnienie daje możliwość szerszej promocji produktu poprzez włączenie go do europejskiej sieci turystycznej EDEN oraz posługiwanie się odznaczeniem Najlepsza destynacja turystyczna w Europie.

W rezultacie podejmowanych działań sieciowy produkt turystyczny Wielki Gościniec Litewski rozwija się, jest rozpoznawalny również poza wschodnim Mazowszem i Podlasiem, przyciąga coraz większą liczbę odbiorców, a oprócz korzyści materialnych, jakie przynosi partnerom, ma również charakter edukacyjny. Wraz z jego realizacją rośnie świadomość mieszkańców subregionu dotycząca możliwości wykorzystywania potencjału lokalnych zasobów kulturowych i przyrodniczych.

Wszystkiedziałaniapromocyjneiorganizacyjnepodejmowanew ramachproduktuprzynoszą wymierne efekty. Jednym z nich jest sprzedaż wycieczek szlakiem Wielki Gościniec Litewski. Produkt pojawia się coraz częściej w katalogach biur podróży. W 2017 r. Biuro Turystyczne „Horn” z Warszawy oferowało wycieczki Szlakiem Unitów Sokołowskich. W 2018 r. wycieczki Szlakiem Wielkiego Gościńca Litewskiego organizowało Biuro Turystyczne „PITUR” z Warszawy. Wycieczki organizuje także Polskie Towarzystwo Turystyczno-Krajoznawcze w Węgrowie. Ma ono w swojej ofercie wycieczki dwudniowe i jednodniowe skierowane głównie do szkół i Uniwersytetów Trzeciego Wieku. Zwiedzanie Muzeum Zbrojowni na Zamku w Liwie jest w ofercie warszawskiego Biura Podróży WIRTUR specjalizującego się w organizacji wycieczek szkolnych i zielonych szkół. Są to najlepsze dowody na powodzenie komercjalizacji sieciowego produktu turystycznego, jakim jest Wielki Gościniec Litewski. 


\section{Folklor i Smaki Mazowsza - Mazowiecka Micha Szlachecka}

Szlaki kulinarne przez zróżnicowanie oraz swoją atrakcyjność pozwalają zachować i chronić dziedzictwo danego obszaru, w tym regionalne dziedzictwo kulinarne.

Szlaki kulinarne wraz z produktami uzupełniającymi odgrywają ważną rolę promocyjną oraz pozwalają na zwiększenie atrakcyjności turystycznej odwiedzanego przez podróżnika regionu [Czarniecka-Skubina 2009, s. 11]. Szlaki te są dość skomplikowanym produktem turystycznym, gdyż obejmują nie tylko oznakowaną trasę i dobrane tematycznie miejsca, ale także imprezy oraz warsztaty kulinarne, usługi noclegowe czy przewodnickie, pamiątki, mapy, przewodniki, jak i wiele innych elementów. Istotnym zadaniem przy tworzeniu tego specyficznego produktu jest bez wątpienia opracowanie jego logo, które w pełni oddawałoby charakter i byłoby znakiem rozpoznawalnym w kraju i zagranicą [Gębica i in. 2014, s. 74-75].

Mazowiecka Micha Szlachecka to produkt skierowany głównie do osób o zainteresowaniach kulinarnych i folklorystycznych. Kreowany jest na bazie regionalnego dziedzictwa kulinarnego, przede wszystkim kuchnię staropolską z wpływami kuchni białoruskiej, litewskiej i żydowskiej. Mazowiecka Micha Szlachecka jest częścią sieciowego produktu Folklor i Smaki Mazowsza realizowanego w województwie mazowieckim, tj. w subregionie siedleckim, a liderami są najprężniej działające restauracje "Zaścianek Polski” i „Dwór Mościbrody”. O rozwoju produktu świadczy zwiększająca się sukcesywnie lista partnerów. Obecnie usługi i atrakcje turystyczne w ramach Mazowieckiej Michy Szlacheckiej oferują restauracje "Zaścianek Polski” i Dwór "Mościbrody”, pałac w Patrykozach (gmina Bielany), gorzelnia w Krzesku i piekarnia „Ratuszowa” w Siedlcach, muzea: Diecezjalne i Regionalne w Siedlcach, Muzeum Ziemiaństwa w Dąbrowie (Oddział Muzeum Regionalnego), Podlaskie Muzeum Techniki Wojskowej i Użytkowej w Bielanach Wąsach (gmina Bielany), gospodarstwo agroturystyczne „Mitowska Zagroda” z Seroczyna (gmina Sterdyń), gospodarstwo pszczelarskie „Tęczowa Pasieka” z Cieciszewa (gmina Konstancin-Jeziorna, powiat piaseczyński), gospodarstwo ekologiczne „EKO na Szerokim” w Wyłazach (gmina Mokobody), Młyn Gąsiorowo (gmina Świercze, powiat pułtuski), Gospodarstwo Produkcyjno-Handlowo-Usługowe „Kowalski” w Winnikach (gmina Nasielsk, powiat nowodworski) oraz Firma Manufaktura Filcu i Grupa Ekologiczna z Siedlec.

W ofercie partnerów sieciowego produktu turystycznego Mazowiecka Micha Szlachecka dostępne są potrawy tradycyjne przyrządzane z lokalnych produktów, co umożliwia turystom poznawanie kuchni tej części regionu. Oprócz atrakcji kulinarnych, na szlaku pojawia się wiele innych możliwości spędzenia czasu, w tym w sposób aktywny. Turyści mogą zwiedzić dwory: w Mościbrodach (gmina Wiśniew) i w Dąbrowie (gmina Przesmyki), Muzeum Diecezjalne z jedynym w Polsce obrazem El Greco „Ekstaza św. Franciszka” w Siedlcach, Bazylikę Mniejszą i Ludwisarnię Braci Kruszewskich w Węgrowie, zespół pałacowo-parkowy w Patrykozach (gmina Bielany) oraz gorzelnię w Krzesku (gmina Zbuczyn) wytwarzającą wódki i nalewki według dawnych receptur. Pozostały czas można spędzić korzystając z atrakcji, takich jak warsztaty kulinarne lub rękodzielnicze, jazda konna, kuligi, wycieczki rowerowe i zabawy przy ognisku oferowane przez obiekty partnerskie. 
W celu zwiększenia atrakcyjności i popularności sieciowego produktu turystycznego Mazowiecka Micha Szlachecka podejmowanych jest szereg przedsięwzięć promocyjnych i organizacyjnych.

Promocja tego produktu odbywa się przy każdym działaniu i wydarzeniu podejmowanym przez liderów lub partnerów produktu. Działania promocyjne, to przede wszystkim udział liderów i partnerów w targach turystycznych krajowych i zagranicznych, konferencjach oraz oprawa kulinarna różnych wydarzeń w postaci przygotowania potraw tradycyjnych i regionalnych. Na potrzeby promocji organizowane jest własne stoisko Mazowieckiej Michy Szlacheckiej lub materiały promocyjne - ulotki, broszury dotyczące atrakcji i karty ofertowe poszczególnych partnerów produktu umieszczane są na stoiskach innych instytucji, np. MROT.

Do najbardziej prestiżowych imprez targowych, na których promowano Mazowieckq Michę Szlachecka zaliczyć można Międzynarodowe Targi Turystyczne TT Warsaw, World Travel Show w Nadarzynie, targi „Na styku kultur” w Łodzi, Międzynarodową Giełdę Turystyczną ITB w Berlinie (promocja na stoisku Konsorcjum „Polskie Szlaki Kulinarne”).

Produkt promowany był także na cyklicznych imprezach wystawienniczych, tj. Międzynarodowych Dniach z Doradztwem Rolniczym, Dniach Siedlec i Jarmarku św. Stanisława w Siedlcach poprzez organizację własnego stoiska z materiałami promocyjnymi (ryc. 2). Duże znaczenie dla popularyzacji produktu miał udział restauracji partnerskich "Zaścianek” i „Dworskie Smaki” w strefie gastronomicznej Festiwalu „Niepodległa”, który odbywał się na Krakowskim Przedmieściu w Warszawie z okazji obchodów 100-lecia odzyskania przez Polskę niepodległości. W ramach festiwalu przygotowana była strefa gastronomiczna "Smaczna Polska”, gdzie obsługa w strojach ludowych serwowała potrawy kuchni polskiej i kuchni regionalnych.

Przedstawiciele liderów i partnerów produktu przeprowadzają pogadanki, prelekcje dotyczące zdrowego stylu życia, a podczas warsztatów kulinarnych łączą to zagadnienie ze staropolskimi tradycjami kulinarnymi. Biorą udział $w$ warsztatach kulinarnych skierowanych do rodziców dzieci z nietolerancją pokarmową lub w warsztatach dla dzieci niepełnosprawnych. Prowadzą również warsztaty ginących zawodów, warsztaty malowania na szkle, filcowania wełny i wiele innych. Promocyjne znaczenie ma również organizacja wycieczek studyjnych dla dziennikarzy i blogerów kulinarnych.

Przedstawiciele szlaku kulinarnego zasiadają w komisjach konkursów kulinarnych lub są fundatorami nagród konkursowych. Uczestniczą także w konferencjach o tematyce turystycznej. Warto zaznaczyć, że partnerami oferującymi usługi i atrakcje turystyczne w ramach Mazowieckiej Michy Szlacheckiej, są głównie podmioty prywatne, a ich działania są przede wszystkim nastawione na zysk, bowiem jest to przedsięwzięcie komercyjne.

Liderzy produktu - restauracja "Zaścianek Polski” wraz ze sklepem ze zdrową żywnością i restauracja "Dwór Mościbrody” - należą do Sieci Dziedzictwa Kulinarnego Mazowsza. Sieć z poszczególnych krajów członkowskich Unii Europejskiej tworzy Europejska Sieć Regionalnego Dziedzictwa Kulinarnego mającą na celu zachowanie tradycji kulinarnych. Uczestnictwo liderów w Sieci to również dodatkowa możliwość promocji Mazowieckiej Michy Szlacheckiej. 


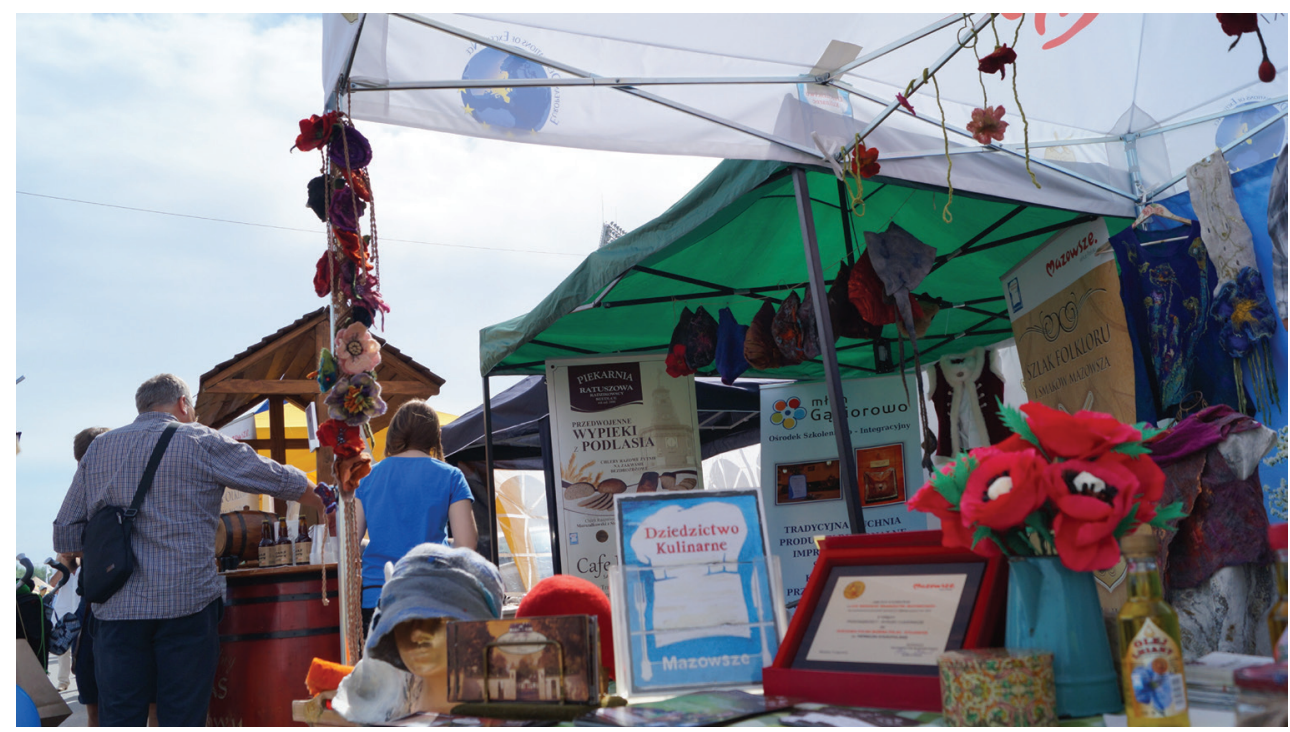

Ryc. 2. Stoisko produktu turystycznego Mazowiecka Micha Szlachecka podczas Międzynarodowych Dni z Doradztwem Rolniczym w Siedlcach Źródło: M. Borkowska, Lider Mazowieckiej Michy Szlacheckiej

W 2015 r. powołano fundację pod nazwą taką samą jak produkt - Mazowiecka Micha Szlachecka, której podstawowym zakresem działań jest edukacja i turystyka. Było to jedno z ważniejszych posunięć organizacyjnych produktu, gdyż powołanie tego typu organizacji umożliwia ubieganie się o dofinansowanie działalności ze środków samorządowych i Funduszy Europejskich, co zwiększa możliwości rozwoju produktu, w tym jego promowania. W 2016 r. fundacja, uzyskując dotację z Urzędu Marszałkowskiego, zrealizowała projekt „Mazowsze na filmowo - „Noce i dnie” w Wodyniach, w ramach którego odbyły się dwudniowe warsztaty kulinarne tzw. „live cooking” - gotowanie na żywo. W tym samym roku i w następnym, fundacja urozmaiciła imprezy dożynkowe powiatu siedleckiego przygotowując degustację potraw tradycyjnych.

Fundacja Mazowiecka Micha Szlachecka, w celu rozwoju produktu, podejmuje współpracę z wieloma instytucjami, co owocuje umocnieniem się produktu na rynku turystycznym. Współpracuje z Polską Organizacją Turystyczną w ramach Konsorcjum „Polskie Szlaki Kulinarne”, które zrzesza podmioty zajmujące się promocją tradycji kulinarnych oraz produktów regionalnych. Współpracuje również z Departamentem Rolnictwa oraz z Departamentem Sportu i Turystyki Urzędu Marszałkowskiego w Warszawie, z Muzeum Diecezjalnym oraz z Muzeum Regionalnym w Siedlcach, z Lokalną Grupą Działania Ziemi Siedleckiej oraz z LOT WGL. W ramach współpracy z LOT WGL przedstawiciele fundacji uczestniczą w Turnieju Smaków w Liwie przygotowując odczyty na temat szlaku kulinarnego oraz biorąc udział w konkursach kulinarnych. W 2017 r. przygotowany przez przedstawicieli Mazowieckiej Michy Szlacheckiej produkt pod nazwą "Suchy prowiant i napitek" - został nagrodzony „Kielichem W. Wielądko” jako najlepszy „Gościniec z podróży”, czyli podarunek 
kulinarny z podróży Wielkim Gościńcem Litewskim. Fundacja Mazowiecka Micha Szlachecka promuje ofertę produktu również poza granicami subregionu, współpracując przykładowo z Fundacją „Vivat Polonia” z Płocka. Współpraca polega m.in. na uczestnictwie w projekcie Dzień Kuchni Polskiej. Jest to projekt współtworzony przez kawiarnie i restauracje z różnych miejsc regionu, które na dzień 11 listopada przygotowują menu składające się z dań kuchni polskiej. Mazowiecka Micha Szlachecka jest promowana również poza granicami województwa, poprzez coroczny udział jej przedstawicieli w Ogólnopolskich Dożynkach Rybackich organizowanych w Dworze Anna w Jakubowicach Konińskich w województwie lubelskim. Fundacja ma własne stoisko promocyjne, zaś liderzy produktu - restauracje "Zaścianek Polski” i „Dwór Mościbrody” biorą udział w konkursach kulinarnych, na których niejednokrotnie zdobywały nagrody za swoje specjały z ryb.

Za działalność na rzecz rozwoju turystyki i propagowanie kuchni tradycyjnej, produkt turystyczny Mazowiecka Micha Szlachecka był wielokrotnie nagradzany. W 2015 r. został wyróżniony w konkursie EDEN, jako obszar turystyczny w Europie z wyróżniającą się ofertą gastronomiczną. W uznaniu zasług dla mazowieckiej turystyki w 2018 r. Fundacja Mazowiecka Micha Szlachecka została nagrodzona przez Marszałka Województwa Medalem Pamiątkowym „Pro Masovia”. Medal jest wyróżnieniem okolicznościowym, nadawanym za całokształt działalności przyczyniającej się do gospodarczego, kulturalnego i społecznego rozwoju Mazowsza.

Działania partnerów na rzecz rozwijania produktu turystycznego Mazowiecka Micha Szlachecka i jego osiągnięcia w rozwoju są tematem wielu wykładów i konferencji dotyczących turystyki. Produkt jest prezentowany jako dobry przykład współpracy i działań partnerskich. Obszar jego funkcjonowania odwiedzają grupy szkoleniowe i turyści z Mazowsza i całej Polski, co świadczy o sukcesie komercjalizacji produktu.

Nadmienić należy, że sieciowy produkt Folklor i smaki Mazowsza, jest realizowany w innych częściach województwa mazowieckiego przez Muzeum Wsi Radomskiej w Radomiu, Muzeum Wsi Mazowieckiej w Sierpcu, Hotel Zamek Pułtusk i Karolin - siedzibę zespołu „Mazowsze”.

\section{Legendy i Baśnie Mazowsza - Kraina Mistrza Twardowskiego}

Inicjatywa stworzenia produktu turystycznego pod nazwą Kraina Mistrza Twardowskiego zrodziła się w 2011 r. w Węgrowie, wśród osób zainteresowanych rozwojem turystyki. Produkt oparty na motywach legendy o Mistrzu Janie Twardowskim jest częścią produktu turystycznego Legendy i Baśnie Mazowsza.

Celem pomysłu było przyciągnięcie turystów na ziemię węgrowską i tym samym zwiększenie dochodów hoteli, restauracji i gospodarstw agroturystycznych oraz rynku zbytu dla rękodzielników.

Liderem produktu zostało gospodarstwo agroturystyczne "Bania na Mazowszu”, a partnerami są: Urząd Miasta w Węgrowie, Oddział PTTK w Węgrowie, stadnina koni w Nowej Wsi Kosowskiej (gmina Kosów Lacki). Oferta Krainy Mistrza Twardowskiego 
obejmuje zwiedzanie Bazyliki Mniejszej w Węgrowie ze znajdującym się tam lustrem Mistrza Jana Twardowskiego oraz możliwość wysłuchania opowieści o jego magicznych właściwościach. Ponad to oferta turystyczna obejmuje inne zabytki Węgrowa, tj. poreformacki zespół klasztorny, kościół ewangelicko-augsburski pod wezwaniem Świętej Trójcy, Dom Gdański z Muzeum Tkaniny Podlaskiej oraz Muzeum Zbrojownię na Zamku w Liwie.

W czerwcu 2013 r. dokonano oficjalnego otwarcia działalności produktu turystycznego. W tym samym roku produkt uzyskał certyfikat Polskiej Organizacji Turystycznej „Najlepszy Produkt Turystyczny Województwa Mazowieckiego". To wyróżnienie dla najbardziej atrakcyjnych, nowatorskich i przyjaznych dla turystów miejsc, imprez lub projektów.

W ciągu trzech lat od spotkania założycielskiego, obok podstawowych atrakcji Krainy Mistrza Twardowskiego, w ofercie znalazły się usługi stadnin koni („Sopyłówka” i „Konik Polny"), operatorów spływów kajakowych na rzece Liwiec oraz wypożyczalni rowerów, uruchomionej nad Zalewem Węgrowskim. Legenda o magu Twardowskim swoje odzwierciedlenie znalazła również w produktach oferowanych przez cukiernie, piekarnie oraz lokalnych rękodzielników, którzy ozdabiają swoje wyroby motywami związanymi z Mistrzem Twardowskim.

Promocję produktu realizowano głównie poprzez organizowanie corocznej imprezy w rocznicę rozpoczęcia działalności Krainy Mistrza Twardowskiego. Program pierwszej z nich, zorganizowanej w 2014 r., obejmował Jarmark Sztuki Ludowej, Rękodzieła i Kuchni Regionalnej, II Mistrzostwa Glazurników Regionu Mazowsze w układaniu lustra Twardowskiego, teatr uliczny, paradę motocykli i wiele innych atrakcji. Druga impreza promocyjna miała charakterplenerowyiodbyłasiępodhasłemLegendy,zabytkiiniepowtarzalne smaki. Na imprezie twórcy ludowi i rękodzielnicy prezentowali oryginalne wyroby ludowe i artystyczne, jak również smaki krainy Twardowskiego - wędliny, miody i napoje. W 2016 r. odbyła się kolejna impreza plenerowa promująca produkt Kraina Mistrza Twardowskiego, podczas której odbyły się koncerty, warsztaty tańca irlandzkiego oraz jarmark.

W ramach działań organizacyjnych w 2015 r. w Urzędzie Miejskim w Węgrowie, który jest partnerem produktu opracowano pieszy Szlak Mistrza Jana Twardowskiego o długości 2 km. Szlak rozpoczyna się na Rynku Mariackim w Węgrowie a kończy nad Zalewem Węgrowskim. Podczas wędrówki można zobaczyć m.in. magiczne lustro Mistrza, odpocząć nad zalewem i wziąć udział w konkursie „Bonus za zwiedzanie”.

Niestety, pomimo początkowego zaawansowania produktu Kraina Mistrza Twardowskiego, dużego potencjału i przygotowanej infrastruktury nastąpił regres w jego rozwoju. Niektóre oferty, wypracowane na początku działalności, już nie funkcjonują. Obecnie, Biuro Turystyczne „Relax” w Węgrowie dysponuje tylko dwiema ofertami pn. Weekend w Krainie Mistrza Twardowskiego oraz Aktywny weekend z natura i historia w Wegrowie $i$ okolicach. W pierwszej ofercie znajduje się zwiedzanie zabytków Węgrowa. Na nocleg zatrzymać się można w hotelu „Everest” z elementami wystroju związanymi z Mistrzem Twardowskim i tu poznać fakty z jego życia lub w gospodarstwie agroturystycznym „Pod Gwiazdami”, w którym spróbować można nalewek i herbat ziołowych sporządzanych według receptur Mistrza. Alternatywną ofertą jest pobyt w Modrzewiowym Dworze w Paplinie koło 
Węgrowa. Dwudniowa oferta, oprócz zwiedzania zabytków Węgrowa, obejmuje aktywny wypoczynek nad Zalewem Węgrowskim oraz wycieczkę rowerową wzdłuż Liwca.

Produkt Kraina Mistrza Twardowskiego w takiej formie, w jakiej został zorganizowany w fazie początkowej, obecnie nie funkcjonuje. Działalność na rzecz produktu Kraina Mistrza Twardowskiego została praktycznie zawieszona i nie jest to przypadek odosobniony. Jak wskazuje B. Wilczyński [2018] „... w Polsce znamy wiele przypadków produktów turystycznych, które zostały uruchomione i promowane, a po okresie finansowania „,zapadały w letarg”, aby „umrzeć” po formalnym okresie trwałości projektu. To już nie sztuka w tych czasach wydać środki na uruchomienie i marketing produktów w czasie trwania projektu, najważniejszym wydaje się znalezienie profesjonalnego rozwiązania i wdrożenie planu na przyszłość, tak aby dany produkt mógł dalej rozwijać się z korzyścią dla wszystkich beneficjentów, (...) Polskie sieciowe produkty turystyczne mają bardzo duży problem z procesem komercjalizacji. Znamy wiele przypadków np. szlaków kulinarnych i szlaków dziedzictwa kulturowego w Polsce, które funkcjonują obecnie tylko w obszarze promocji tylko pozostają oznakowane i opisane w Internecie. Brak jednak w ich przypadku dalszych pomysłów na zarządzanie i sprzedaż wspólnej oferty przez touroperatorów i wykorzystanie ich potencjału do rozwoju gospodarczego danego obszaru".

Przyczyn zawieszenia działalności produktu Kraina Mistrza Twardowskiego należy upatrywać w braku lidera (lider zrezygnował z reprezentowania produktu), braku organizacji lub stowarzyszenia powołanego do skupienia wszystkich członków pod jedną nazwa co umożliwiłoby ubieganie się o dotacje. Na ograniczenie działalności produktu wpłynął brak wsparcia merytorycznego i finansowego ze strony władz miasta Węgrowa (co wynikało ze zmian we władzach miasta). Produkt mógłby wznowić swoją działalność w wyniku pozytywnego impulsu, jakim mogłoby być powstanie organizacji czy stowarzyszenia oraz powołanie nowego lidera do jego reprezentacji.

Warto zaznaczyć, że mimo zaprzestania działalności w ramach Krainy Mistrza Twardowskiego, sieciowy produkt turystyczny Legendy i Baśnie Mazowsza powoli rozwija się w pozostałej części województwa. Do sieci produktu dołączył Park Rozrywki Julinek w Lesznie k. Warszawy oraz Park Edukacji i Rozrywki Farma Iluzji w Mościskach w gminie Trojanów. Park Rozrywki Julinek mieści się na terenie dawnej Bazy Cyrkowej w Julinku. Park oferuje beztroską zabawą dla całej rodziny na łonie natury. Stara się także chronić dziedzictwo polskiej sztuki cyrkowej oraz upowszechnić wiedzę o niej wśród swoich gości. Farma Iluzji to rodzinny park rozrywki z torami przeszkód, iluzjami optycznymi oraz pokazami magii. 


\section{Podsumowanie}

Produkt turystyczny odpowiadający na potrzeby turystów jest warunkiem sine qua non dyskontowania wszystkich pozytywnych efektów, jakie dla rozwoju regionu i jego mieszkańców mogą płynąć z rozwoju turystyki w aspekcie gospodarczym, społecznym, przestrzennym, kulturowym. Produkt turystyczny, aby odnieść sukces rynkowy, powinien mieć kilka pożądanych przez rynek cech: powinien być unikatowy, czyli bazujący na potencjałach lokalnych, maksymalizujący korzyści - potencjalne korzyści z zakupu produktu muszą być większe niż te, na które może liczyć turysta w miejscu swojego zamieszkania. Ważne jest również by produkt turystyczny odpowiadał na zmieniające się modele konsumpcji - np. specjalizacja w zależności od odbiorcy - dla seniorów, dla rodzin z dziećmi, dla singli, dla hobbystów oraz umożliwiał celebrowanie doświadczeń, odwoływał się do sfery doznań i emocji, angażował zmysły [Wilk-Grzywna 2015].

Sieciowe produkty turystyczne Wielki Gościniec Litewski, Mazowiecka Micha Szlachecka i Kraina Mistrza Twardowskiego skomercjalizowano w 2013 r., opracowując pakiety ofert produktowych gotowych do sprzedaży przez biura podróży lub punkty informacji turystycznej. W ciągu 5 lat od komercjalizacji widoczny jest rozwój dwóch produktów: Wielki Gościniec Litewski i Mazowiecka Micha Szlachecka oraz znaczące wyhamowanie działalności w ramach produktu Kraina Mistrza Twardowskiego.

Rozwój dwóch ww. produktów to przede wszystkim prowadzenie na szeroką skalę ich promocji, poszerzenie listy partnerów w sieci, udoskonalanie ofert poprzez wprowadzanie nowych atrakcji. Świadczy to o zaangażowaniu i intensywności pracy liderów oraz partnerów w sieci. Współpraca pomiędzy poszczególnymi partnerami przynosi efekty dla produktu i dla partnerów w postaci zwiększonego ruchu turystycznego, tym samym przyczynia się do zwiększenia popytu na lokalne wyroby i usługi. Oceniając ww. sieciowe produkty turystyczne należy podkreślić ich pozytywną rolę w rozwoju społeczno-gospodarczym subregionu siedleckiego.

Funkcjonowanie produktów przyczynia się do poznania historii i tradycji regionu, w tym dziedzictwa kulinarnego. W subregionie siedleckim zlokalizowana jest duża liczba gospodarstw agroturystycznych. Wiele z nich stało się partnerami w omawianych produktach turystycznych i dzięki temu agroturystyka może się rozwijać bardziej intensywnie. Ma to szczególne znaczenie w obszarach o niekorzystnych warunkach gospodarowania, jakim jest omawiany subregion. Imprezy plenerowe organizowane w ramach tych ofert to dla wielu producentów możliwość promocji i sprzedaży wyrobów spożywczych i rękodzielniczych, a tym samym możliwość powiększenia swoich dochodów. Jest to szczególnie istotne w produkcie Wielki Gościniec Litewski z uwagi na to, że wzdłuż gościńca litewskiego mieszka wiele osób uprawiających tzw. ginące zawody - kowalstwo, garncarstwo, tkactwo, wycinankarstwo i inne, i to dla nich imprezy plenerowe stanowią okazję zbytu własnych wyrobów.

Produkt turystyczny - Mazowiecka Micha Szlachecka, będący szlakiem kulinarnym, odgrywa pozytywną rolę w subregionie. Jak podkreślają P. Dominik i D. Zadrożna [2014] 
„...szlaki kulinarne mają tzw. multiwytwarzalny charakter polegający na włączaniu w ich tworzenie wielu podmiotów. Jest to korzystne z punktu widzenia rozwoju regionalnego, możliwości zaangażowania się instytucji oraz wytwórców indywidualnych, jak również włączania coraz to nowych atrakcji. Szlaki kulinarne muszą być tworzone zgodnie z zasadami dobrej organizacji szlaków kulturowych, a wówczas, jako sprawnie funkcjonujące, mogą być produktem turystycznym. Nie do przecenienia jest rola edukacyjna szlaków, dzięki którym tematyka kulinarna może również łączyć pokolenia".

Pozytywny wpływ Mazowieckiej Michy Szlacheckiej w subregionie siedleckim następuje m.in. poprzez zatrudnienie wielu osób do obsługi kulinarnej wydarzeń kulturalnych i plenerowych, które organizuje lub których uczestnikiem jest Fundacja Mazowiecka Micha Szlachecka. Pozytywna rola tego produktu wynika również z obecności partnerów we wszelkiego rodzaju wydarzeniach umożliwiających promocję atrakcji turystycznych subregionu i przyciąganie turystów lub zbywanie wytworzonych towarów spożywczych i rękodzielniczych. Funkcjonowanie produktów turystycznych to również zwiększenie produkcji drobnej przedsiębiorczości (piekarni, cukierni itp.).

Oceniając produkty turystyczne $\mathrm{w}$ subregionie siedleckim nie uwzględniono ich skuteczności rynkowej. Wynika to z braku jednolitych kryteriów monitorowania efektów ekonomicznych oraz zbyt krótkiego czasu ich funkcjonowania. Wypracowanie przydatnych do tego wskaźników może nastręczyć wiele kłopotów, gdyż w działalność produktów zaangażowani są partnerzy finansowani ze środków publicznych, jak i podmioty nastawione na zysk (osoby fizyczne, przedsiębiorstwa prywatne).

Dalsze funkcjonowanie produktów turystycznych i ich rozwój wymaga:

- stałego promowania produktów przy wykorzystaniu różnych narzędzi marketingowych w celu dotarcia do odbiorców nie tylko z regionu, ale i krajowych,

- stałego wsparcia merytorycznego ze strony MROT poprzez organizację konferencji i warsztatów oraz konsultacji dla partnerów produktów,

- łączenia w sieci ludzi, miejsc, firm wzajemnie uzupełniających swoje usługi dla rozwoju sieci produktów,

- rozwiązań prawnych umożliwiających współpracę instytucji państwowych z osobami prywatnymi na rzecz produktu,

- stałego doskonalenia ofert już istniejących i opracowania nowych ofert uwzględniających aktualne trendy w turystyce; ofert innowacyjnych, całorocznych, skierowanych do konkretnej grupy odbiorców oraz angażujących wszystkich partnerów w sieci,

- wsparcia finansowego z różnych źródeł ( $\mathrm{z}$ instrumentów wojewódzkich i unijnych),

- oznakowania obiektów położonych w zasięgu funkcjonowania produktów,

- inwestycji w infrastrukturę turystyczna, w tym rozbudowy bazy noclegowej ogólnodostępnej oraz paraturystyczną dla pełniejszego wykorzystania walorów turystycznych subregionu.

Utrzymanie na bardzo konkurencyjnym rynku turystycznym wykreowanych produktów turystycznych mogłoby przyczynić się do dostrzeżenia Mazowsza jako atrakcyjnej destynacji dla podróży weekendowych i pobytów wakacyjnych, tym samym skierowania ruchu 
turystycznego w dotychczas mało wykorzystane, a równie atrakcyjne turystycznie rejony województwa mazowieckiego.

\section{Literatura}

Czarniecka-Skubina E., 2009, Szlaki Kulinarne. Turystyka kulinarna w Polsce, Przegląd Gastronomiczny, 2, s. 11.

Dominik P. (red.), Zadrożna D., 2014, Szlak kulinarny jako produkt turystyczny [w:] P. Dominik (red.), Szlaki kulinarne jako element turystycznej atrakcyjności regionu Mazowsze, Urząd Marszałkowski Województwa Mazowieckiego, Warszawa.

Dymna B., 2018, Kreowanie sieciowych produktów turystycznych w województwie mazowieckim, MAZOWSZE Studia Regionalne, 24, Mazowieckie Biuro Planowania Regionalnego, Warszawa.

Gadomska U. (red.), Dymna B., Gurbała M. i in., 2015, Koncepcje sieciowych produktów turystycznych w subregionach województwa mazowieckiego, MAZOWSZE Analizy i Studia, 7, 48, Mazowieckie Biuro Planowania Regionalnego, Warszawa.

Gębica P., Krupa J.(red.), Niemiec W., Szpara K., Superson S., 2014, Szlaki kulinarne jako produkt turystyczny - metody promocji [w:] Nowoczesne metody $i$ narzędzia wsparcia w rozwoju matych destynacji turystycznych, Związek Gmin Turystycznych Pogórza Dynowskiego, Dynów, s. 74-75.

Kachniewska M., 2015, Model tworzenia sieciowego produktu turystycznego, Mazowiecka Regionalna Organizacja Turystyczna, Warszawa.

Majewska I., Telniuk T., Broma i in., 2008, Program rozwoju produktów turystyki aktywnej i kulturowej w województwie mazowieckim, Polska Agencja Rozwoju Turystyki S.A., Warszawa.

Orłowski D., Woźniczko M., 2015, Turystyka kulinarna na wiejskim rynku turystycznym, Studia Komitetu Przestrzennego Zagospodarowania Kraju, 163, Warszawa.

Program rozwoju sieciowych produktów turystycznych województwa mazowieckiego, 2011, Mazowiecka Regionalna Organizacja Turystyczna, Warszawa.

Wilczyński B., 2018, Wschodni Szlak Rowerowy Green Velo - mocny start i co dalej? - głos w dyskusji na temat dalszego rozwoju sieciowego produktu turystycznego, Biuletyn Komitetu Przestrzennego Zagospodarowania Kraju, 269, Warszawa.

Wilk-Grzywna M., 2015, Skuteczna komunikacja marketingowa produktu turystycznego w aspekcie rozwoju regionalnego na przykładzie Wschodniego Szlaku Rowerowego Green Velo, Studia Komitetu Przestrzennego Zagospodarowania Kraju, 166, Warszawa. 


\section{Strony internetowe}

www.edenpolska.pl

www.krainatwardowskiego.pl

www.liw-zamek.pl

www.mazowsze.travel

www.modanamazowsze.pl

www.mrot.pl

www.mttargi.pl

www.wielkigoscinieclitewski.pl

www.mazowszeravel.pl

Inne źródła

Informacje uzyskane od liderów produktów turystycznych oraz z Mazowieckiej Regionalnej Organizacji Turystycznej. 


\section{An overview of the activities concerning selected network tourism products of the Siedlce subregion}

\section{ABSTRACT}

In 2011-2013, the Mazovian Regional Tourist Organization (MROT), along with tourist market stakeholders, implemented a project called "Raising Mazovia's tourism competitiveness by implementing network tourism products". In effect, MROT developed and commercialized 16 network tourism products.

The proposed network tourism products are an attempt at overcoming the lack of integration between the tourist offer of Warsaw and the unexploited elements of Mazovia's subregions: siedlecki, radomski, płocki, ciechanowski and ostrołęcki. The development of tourism through the commercialization of network tourism products is one of the possible ways of reviving these subregions in social and economic terms. The functioning of tourist products requires the constant involvement of product leaders and partners as well as advice, instructions and financial support from the regional government and tourist organizations, including the Mazovian Regional Tourist Organization.

The purpose of this article is to characterize three of the 16 network tourism products developed by MROT in the Siedlce subregion: Wielki Gościniec Litewski (The Great Lithuanian Trade Route), Mazowiecka Micha Szlachecka (The Mazovian Nobleman's Dish) and Kraina Mistrza Twardowskiego (The Land of Mage Twardowski). The article presents the promotional and organizational activities undertaken over the last 5 years in order to develop network products and strengthen their position on the tourist market. The three Siedlce subregion products were classified by MROT among the most advanced in terms of commercialization thanks to the intense activity of the people involved in their creation.

Key words: network tourist product, promotional and organizational activities, socio-economic development

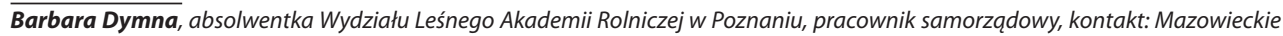
Biuro Planowania Regionalnego w Warszawie, OT Siedlce, ul. Pułaskiego 19/21, 08-110 Siedlce, e-mail: bdymna@mbpr.pl

Barbara Dymna, a graduate of the Forestry Faculty of the Agricultural Universty of Poznan, public administration employee, contact: Mazovian Office for Regional Planning in Warsaw, Branch office in Siedlce, ul. Pułaskiego 19/21, 08-110 Siedlce, e-mail:bdymna@mbpr.pl 